
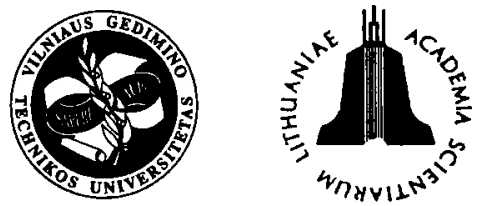

JOURNAL OF CIVIL ENGINEERING AND MANAGEMENT

http:/www.vtu.lt/english/editions

2002, Vol VIII, No 3,169-176

\title{
RESONANT FREQUENCY IN POLYPROPYLENE FIBRE REINFORCED CONCRETE (PFRC) WITH POZZOLANIC MATERIALS
}

\author{
Hau Y. Leung, Ramapillai V. Balendran \\ Dept of Building \& Construction, City University of Hong Kong. \\ Tat Chee Avenue, Kowloon, Hong Kong.E-mail: bchyl@cityu.edu.hk
}

Received 09 Nov 2001; accepted 12 June 2002

\begin{abstract}
In this study, the resonant frequency of polypropylene fibre reinforced concrete (PFRC) under three different curing conditions was investigated and the influences of fly ash (PFA) and silica fume (SF) on PFRC under the same curing condition were also studied. The experiments were carried out in the Heavy Laboratory of City University of Hong Kong. Four types of concrete mixes were tested. A total of 24 concrete specimens were prepared. Test results show that the resonant frequency can be affected by the presence of polypropylene fibres, partial replacement of cement by silica fume or pulverized fly ash, and curing condition.
\end{abstract}

Keywords: concrete, resonant frequency, polypropylene fibres, pozzolans, silica fume, pulverized fly ash, curing.

\section{Introduction}

High-strength concrete with compressive strength higher than $41,0 \mathrm{~N} / \mathrm{mm}^{2}$ ( $6000 \mathrm{psi}$ ) is being used in the construction of buildings, and other reinforced and prestressed concrete structures. One major drawback of highstrength concrete is that it is brittle with low tensile strength and strain. The failure of high-strength concrete structure may be sudden in particular when it is subjected to loadings like earthquake and blast. An ideal solution to overcome the disadvantage of high-strength concrete is to add fibres in the concrete so as to convert it into a comparatively ductile material and to avoid sudden failures [1, 2].

Being used in discontinuous form, fibres are distributed inside the concrete matrix. Therefore they can be considered as secondary reinforcement for controlling cracks due to humidity or temperature changes and cracks due to tensile stress [1].

The use of fibrous reinforced concrete has still been in the research phase in the structural building materials area. However, most of the fibres used extensively today are carbon, glass, natural fibres, polypropylene and steel. The last two are the most widely used in conventionally placed concrete [3]. Considering the economical and corrosive reasons, the polypropylene fibres have a high potential to be used in future [4]. So far, very limited research on behaviour of concrete members reinforced with polypropylene fibres can be found.

According to ACI Committee 544 [5], some pozzolans, such as pulverized fly ash (PFA) and silica fume (SF) would have a great contribution in fibre reinforced concrete (FRC). The incorporation of pozzolans can improve the mechanical properties of concrete in both fresh state and hardened state. Besides, not only the pozzolans may affect the properties, the curing condition can also alter the properties of hardened concrete [6].

The objectives of this study are (1) to analyze the resonant frequency of PFRC under the influence of the partial substitution of cement with pulverized fly ash (PFA) and silica fume (SF), and (2) to investigate the influence of the curing conditions on resonant frequency of PFRC with and without partial replacement of cement by PFA and SF.

\section{Details of experiments}

All the experiments were carried out in the Heavy Structures Testing Laboratory in the Dept of Building \& Construction at City University of Hong Kong, Hong Kong.

\subsection{Concrete mixes}

Four different mixes were designed and given in Table 1. The mix proportions of the four mixes were very similar. Three mixes (Mixes $\mathrm{CP}, \mathrm{CPF}$ and $\mathrm{CPS}$ ) were made using polypropylene fibres containing about $0,2 \%$ by volume of the concrete. The polypropylene fibres were produced from the W.R. Grace (Hong Kong) Limited, the fibres are alkali resistant, non-absorptive, and completely non-corrosive. Some general physical properties are shown in Table 2 . 
Table 1. Mix proportion of each mix

\begin{tabular}{|l|c|c|c|c|}
\hline \multicolumn{1}{|c|}{$\begin{array}{c}\text { Mix } \\
\text { type }\end{array}$} & $\begin{array}{c}\text { Mix C } \\
\text { Ordinary Portland } \\
\text { cement concrete } \\
\text { (OPC) }\end{array}$ & $\begin{array}{c}\text { Mix CP } \\
\text { Fibre reinforced } \\
\text { concrete } \\
\text { (PFRC) }\end{array}$ & $\begin{array}{c}\text { Mix CPF } \\
\text { Fibre reinforced } \\
\text { fly ash concrete }\end{array}$ & $\begin{array}{c}\text { Mix CPS } \\
\text { Fibre reinforced } \\
\text { silica fume concrete }\end{array}$ \\
\hline \multicolumn{1}{|c|}{ Cement } & 360 & 360 & 324 & 324 \\
\hline $\begin{array}{l}\text { Coarse aggregates } \\
20 \mathrm{~mm}\end{array}$ & 720 & 720 & 720 & 720 \\
$10 \mathrm{~mm}$ & 400 & 400 & 400 & 700 \\
\hline Fine aggregates & 700 & 700 & 700 & 180 \\
\hline Water & 180 & 180 & 2,58 & 2,58 \\
\hline Polypropylene fibre & - & 2,58 & 36 & - \\
\hline Fly ash & - & - & - & 36 \\
\hline Silica fume & - & - & 1800 & 1800 \\
\hline $\begin{array}{l}\text { Superplasticier } \\
\text { Daracem 100 } \\
\text { (5cc./kg) }\end{array}$ & 1800 & 1800 & & 180 \\
\hline
\end{tabular}

Note: * The amount of Daracem 100 is dependent on the cement used.

$5 \mathrm{cc}$. of Daracem 100 will be used per $1 \mathrm{~kg}$ of cement.

Mixes CPF and CPS contained $10 \%$ fly ash and $10 \%$ silica fume respectively to replace the same amount of cement (by weight). The water/cement ratio of 0,5 was used for each mix. Also the same amount of superplasticizer (Daracem 100) was added into the mix so as to facilitate easy mixing. Mixing of concrete was done in a rotary mixer.

Table 2. Properties of polypropylene fibres [7]

\begin{tabular}{|l|c|}
\hline \multicolumn{1}{|c|}{ Specific gravity } & 0.91 \\
\hline Absorption & None \\
\hline Modulus of elasticity & $3500 \mathrm{~N} / \mathrm{mm}^{2}$ \\
\hline Melt point & $160^{\circ} \mathrm{C}$ \\
\hline Ignition point & $590^{\circ} \mathrm{C}$ \\
\hline Alkali, acid, salt resistance & High \\
\hline
\end{tabular}

\subsection{Concrete specimens and curing}

Six $100 \times 100 \times 500 \mathrm{~mm}$ plain concrete beams for each of the four mixes were cast. Being covered with plastic sheets for 24 hours to prevent evaporation of water from the fresh concrete, the specimens were then demoulded after 24 hours. Afterwards, they were stored in different places under different curing conditions. Three different conditions were adopted to cure the hardened concrete specimens and they are described as follows.

\section{Condition a}

Air curing at $25^{\circ} \mathrm{C}$ and humidity $65 \%$

\section{Condition 27w}

Water curing at $27^{\circ} \mathrm{C}$ for 7 days and then return to air curing at $25^{\circ} \mathrm{C}$ and humidity $65 \%$

\section{Condition $38 \mathrm{w}$}

Water curing at $38^{\circ} \mathrm{C}$ for 7 days and then return to air curing at $25^{\circ} \mathrm{C}$ and humidity $65 \%$

\subsection{Resonant frequency test}

Malhotra et al. [8] stated that it was used almost exclusively in the laboratory and involved the determination of the natural frequencies of vibration of concrete prisms. The frequency of a vibration applied to a body was equal to one of the natural frequency of vibration of that body. This condition was called resonance. This frequency could be obtained due to the maximising amplitude of the vibration in the body. However, the frequency should be fundamental frequency that was the lowest resonant frequency of the concrete. Table 3 recommends the range of frequencies on different size of specimens.

Table 3. Range of longitudinal fundamental resonant frequencies of concrete prisms and cylinder specimen [9]

\begin{tabular}{|c|c|}
\hline $\begin{array}{c}\text { Size of specimens } \\
(\mathrm{mm})\end{array}$ & $\begin{array}{c}\text { Approximate range of frequency } \\
(\mathrm{Hz})\end{array}$ \\
\hline $150 \times 150 \times 750$ & $1700-3000$ \\
\hline $150 \times 150 \times 700$ & $2000-3200$ \\
\hline $100 \times 100 \times 750$ & $1700-3000$ \\
\hline $100 \times 100 \times 500$ & $3000-4500$ \\
\hline $100 \times 100 \times 300$ & $5000-7000$ \\
\hline $150 \times 300$ cylinder & $5000-7000$ \\
\hline
\end{tabular}

The test apparatus, as required by BS 1881 [10], includes a vibrator which vibrates the concrete at the point of contact at a given frequency, and a sensor which picks up the vibration at the other end of the specimen. Generally, longitudinal mode of vibration will be tested in this study. That means the compressive waves travel through a specimen in the direction parallel to its length.

The resonant frequency test is complied with the BS 1881 [10]. The resonant frequency was corrected to nearest $0,5 \mathrm{~Hz}$. The procedures of resonant frequency test can be summarised as follows. 
1. The beam specimen was clamped or balanced at its centre on the fixed support.

2. Grease was used to provide a good contact between the vibrator/pick-up rods and the concrete surface.

3. The vibrator and the pick-up rods were moved so that both of them were just in contact with the centre of the end surfaces of beam. Then the supports were locked by using the knurled clamping screws.

4. The apparatus was switched on. The output voltage control was adjusted to 1 volt.

5. With reference to Table 3, the resonant frequency of the test beams was within the $3000-4500 \mathrm{~Hz}$ range.

6. The frequency was gradually increased.

7. The frequency of vibrator should be varied until a resonance was obtained and the frequency was recorded. Resonance was recognized when the indicator showed a peak response and a large and sharp sound would be produced.

8. In order to obtain the fundamental frequency accurately, the frequency of excitation was varied below and above the resonance frequency and to test whether the indicator showed another peak response.

\section{Results \& discussion}

All experimental results are given in Table 4 and some variations are plotted in Fig 1.

\subsection{Development of resonant frequency}

Referring to Fig 1 , the resonant frequency of all mixes on the test beams increased rapidly at 3 days and then the increase was retarded after that. Table 5 shows the percentage change of the development of resonant frequency relative to that at 28 days.

From Table 5, the frequencies at 3 days and 7 days were about $93 \%$ and $98 \%$ of that at 28 days while the frequency at 91 days was $1 \%$ more than the frequency of 28 days. The frequency increases with age because the reaction products of hydration decrease the porosity with age. At early ages, the reactants (cement and water) are enough to allow the hydration to progress in a fast rate. Therefore the resonant frequency increases rapidly. However, the amount of reactants decreases with age, the gain in resonance frequency increases slowly at later ages ( 28 and 91 days).

\subsection{Resonant frequency of PFRC}

From Fig 1, mix CP shows slightly lowered resonant frequency than mix $\mathrm{C}$. With the addition of polypropylene fibres in Portland cement concrete, the resonant frequency is slightly decreased under the three examined curing conditions. Table 6 shows the percentage change of mix CP when compared with mix C.

From Table 6, the resonant frequency of mix $\mathrm{CP}$ indicates no significant difference but the frequency of mix $\mathrm{CP}$ is slightly lower than those of mix $\mathrm{C}$. The percentage change varies from $-1,8 \%$ to $-0,3 \%$. The reason is that the resonant frequency test is dependant upon both the vibration frequency of the sample and the density. The density of polypropylene fibres is lower than those of aggregate and the mortar. As a result, the presence of polypropylene fibre in the Portland cement concrete produces lowered resonance frequency than the control specimens (without fibre). However, the volume fraction of polypropylene fibre is only $0,2 \%$, its effect is not considerable.

\subsection{Resonant frequency of PFRG under the influ- ence of PFA}

From Fig 1, with the partial replacement of cement by PFA in PFRC, mix CPF gives slightly lowered resonant frequency than the mix $\mathrm{CP}$ at early ages $(3$ and 7 days) while a slightly higher resonant frequency is shown in mix CPF than mix CP at later ages (28 and 91 days). Table 7 shows the percentage change of mix CPF compared with mix CP.

Table 4. Experimental results of resonant frequency

\begin{tabular}{|c|c|c|c|c|c|}
\hline \multirow{2}{*}{$\begin{array}{c}\text { Curing } \\
\text { condition }\end{array}$} & \multirow{2}{*}{ Mix } & \multicolumn{4}{|c|}{ Average resonant frequency (Hz) } \\
\cline { 2 - 6 } & & 3 days & 7 days & 28 days & 91 days \\
\hline \multirow{3}{*}{$\begin{array}{c}\text { Air (a) } \\
\text { curing }\end{array}$} & $\mathrm{C}$ & 3500 & 3628 & 3764 & 3794 \\
\cline { 2 - 6 } & $\mathrm{CP}$ & 3436 & 3598 & 3713 & 3731 \\
\cline { 2 - 6 } & $\mathrm{CPF}$ & 3430 & 3580 & 3707 & 3732 \\
\hline \multirow{3}{*}{$\begin{array}{c}27 \mathrm{w} \\
\text { curing }\end{array}$} & $\mathrm{CPS}$ & 3538 & 3675 & 3798 & 3820 \\
\cline { 2 - 6 } & $\mathrm{C}$ & 3593 & 3789 & 3862 & 3905 \\
\cline { 2 - 6 } & $\mathrm{CP}$ & 3580 & 3760 & 3875 & 3919 \\
\hline \multirow{3}{*}{$\begin{array}{c}38 w \\
\text { curing }\end{array}$} & $\mathrm{CPF}$ & 3553 & 3722 & 3913 & 3945 \\
\cline { 2 - 6 } & $\mathrm{CPS}$ & 3644 & 3834 & 3930 & 3980 \\
\cline { 2 - 6 } & $\mathrm{C}$ & 3707 & 3873 & 3940 & 3977 \\
\cline { 2 - 6 } & $\mathrm{CP}$ & 3676 & 3855 & 3928 & 3951 \\
\hline
\end{tabular}



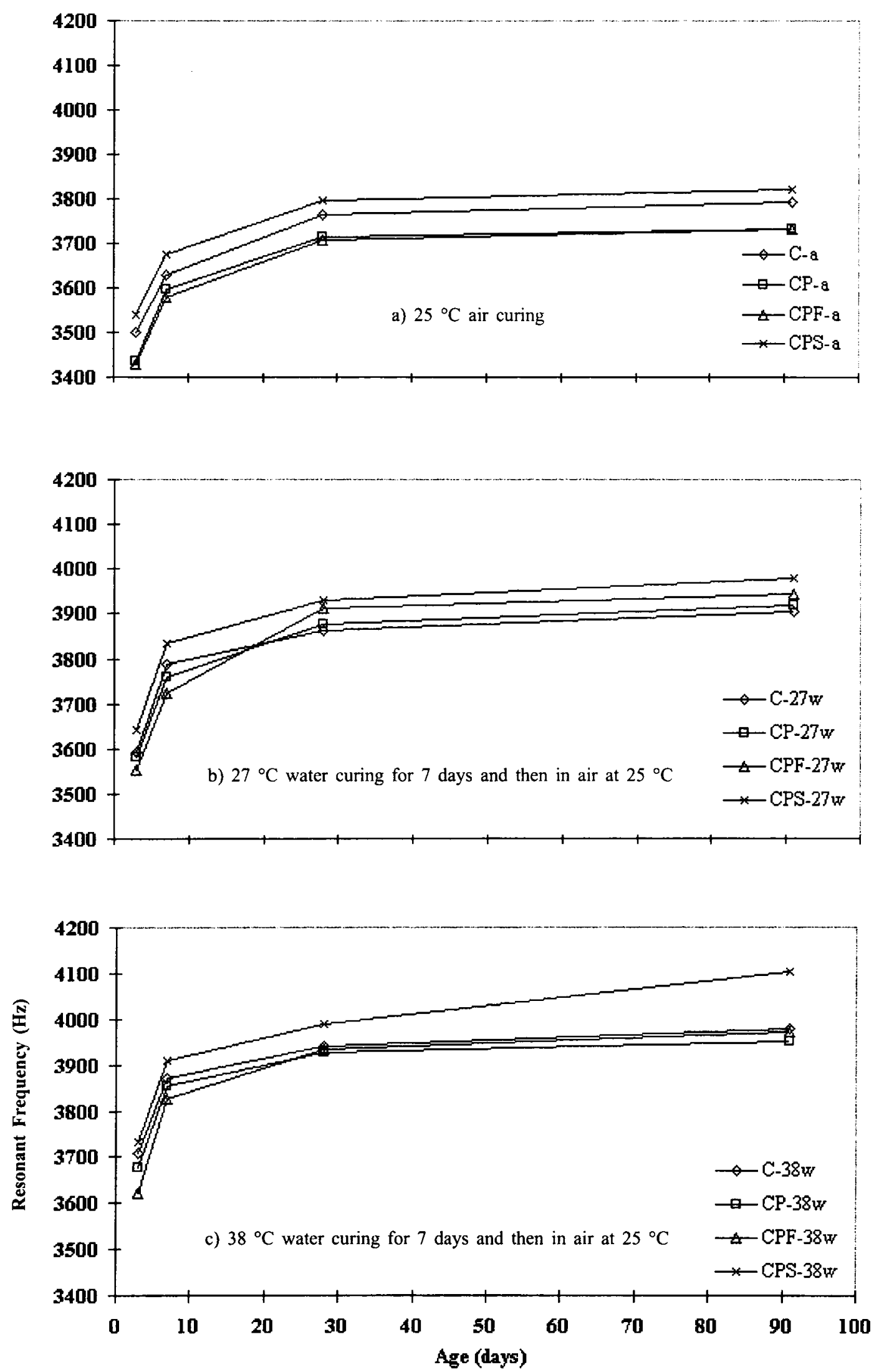

Fig 1. Variation of resonant frequency of all mixes with age under different curing conditions 

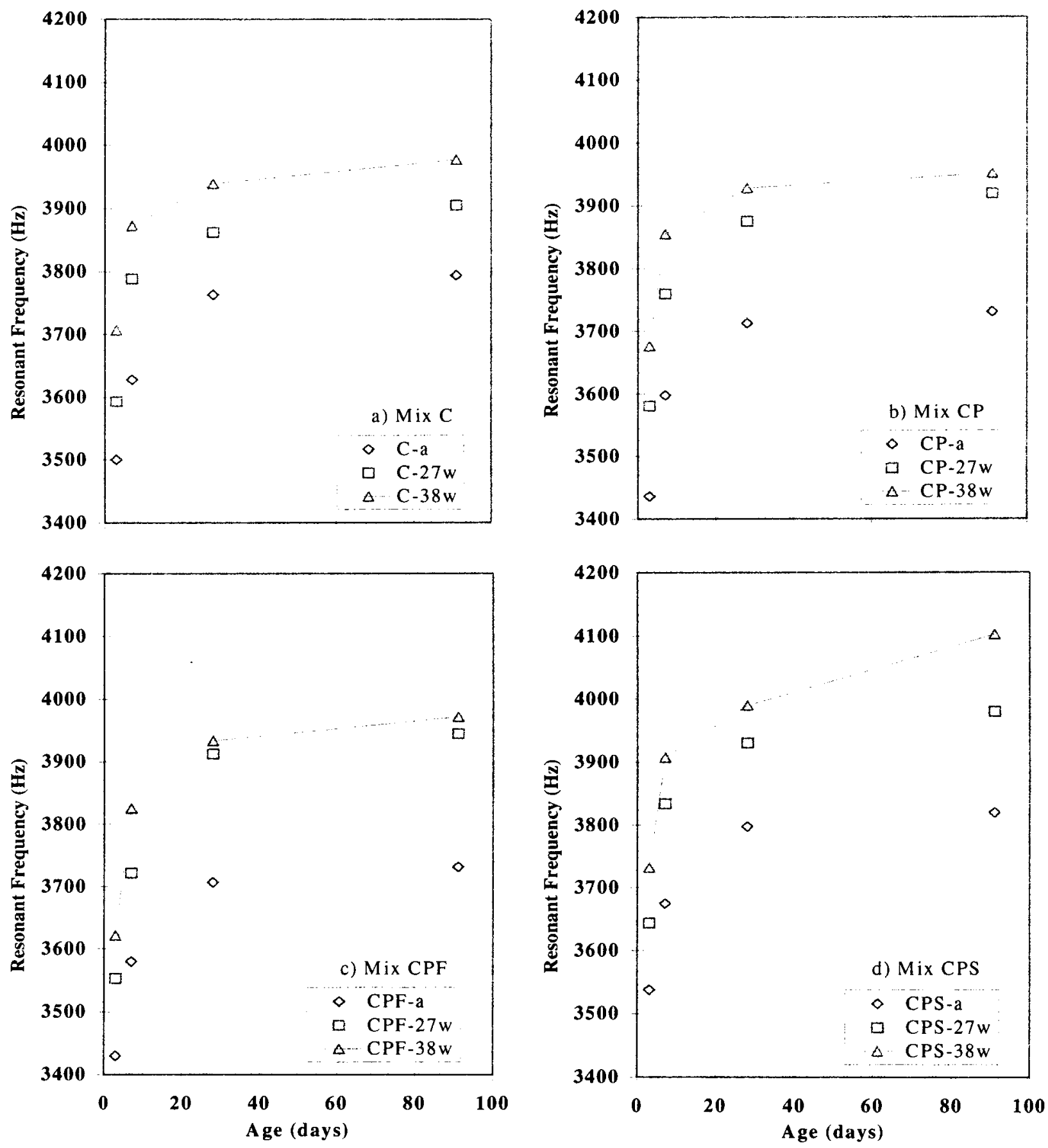

Fig 2. Comparison of resonant frequency of a) mix $\mathrm{C}, \mathrm{b}$ ) mix $\mathrm{CP}$, c) mix $\mathrm{CPF}$ and d) mix CPS under three curing conditions with age 
Table 5. The percentage change of resonant frequency relative to 28 days for each mix

\begin{tabular}{|c|c|c|c|c|c|c|c|c|c|}
\hline \multirow{2}{*}{ Mix } & \multirow{2}{*}{$\begin{array}{c}\text { Curing } \\
\text { conditions }\end{array}$} & \multicolumn{4}{|c|}{ Resonant frequency (Hz) } & \multicolumn{3}{c|}{$\begin{array}{c}\text { Percentage change compared with } 28 \\
\text { days of each mix under each curing } \\
\text { condition }\end{array}$} \\
\cline { 3 - 11 } & & $\begin{array}{c}3 \\
\text { days }\end{array}$ & $\begin{array}{c}7 \\
\text { days }\end{array}$ & $\begin{array}{c}28 \\
\text { days }\end{array}$ & $\begin{array}{c}91 \\
\text { days }\end{array}$ & $\begin{array}{c}3 \\
\text { days }\end{array}$ & $\begin{array}{c}7 \\
\text { days }\end{array}$ & $\begin{array}{c}28 \\
\text { days }\end{array}$ & $\begin{array}{c}91 \\
\text { days }\end{array}$ \\
\hline C & & 3500 & 3628 & 3763,5 & 3794 & $93 \%$ & $96 \%$ & $100 \%$ & $101 \%$ \\
\hline CP & a & 3436 & 3597,5 & 3712,5 & 3730,5 & $93 \%$ & $97 \%$ & $100 \%$ & $100 \%$ \\
\hline CPF & & 3430 & 3580 & 3707 & 3731,5 & $93 \%$ & $97 \%$ & $100 \%$ & $101 \%$ \\
\hline CPS & & 3538 & 3675 & 3797,5 & 3820 & $93 \%$ & $97 \%$ & $100 \%$ & $101 \%$ \\
\hline C & & 3593 & 3788,5 & 3862 & 3905 & $93 \%$ & $98 \%$ & $100 \%$ & $101 \%$ \\
\hline CP & $27 w$ & 3580 & 3760 & 3875 & 3919 & $92 \%$ & $97 \%$ & $100 \%$ & $101 \%$ \\
\hline CPF & & 3553 & 3722 & 3913 & 3945 & $91 \%$ & $95 \%$ & $100 \%$ & $101 \%$ \\
\hline CPS & & 3643,5 & 3834 & 3930 & 3980 & $93 \%$ & $98 \%$ & $100 \%$ & $101 \%$ \\
\hline C & & 3706,5 & 3872,5 & 3939,5 & 3977 & $94 \%$ & $98 \%$ & $100 \%$ & $101 \%$ \\
\hline CP & $38 w$ & 3676 & 3855 & 3928 & 3951 & $94 \%$ & $98 \%$ & $100 \%$ & $101 \%$ \\
\hline CPF & & 3622 & 3825,5 & 3933,5 & 3972 & $92 \%$ & $97 \%$ & $100 \%$ & $101 \%$ \\
\hline CPS & & 3732 & 3907,5 & 3990 & 4102 & $94 \%$ & $98 \%$ & $100 \%$ & $103 \%$ \\
\hline
\end{tabular}

Notes: ${ }^{*}$ a $=$ air curing at $25^{\circ} \mathrm{C}$ and $65 \%$ RH. at all ages

$27 \mathrm{w}=$ water curing at $27^{\circ} \mathrm{C}$ for 7 days and then air curing at $25^{\circ} \mathrm{C}$ and $65 \% \mathrm{RH}$.

$38 \mathrm{w}=$ water curing at $38^{\circ} \mathrm{C}$ for 7 days and then air curing at $25^{\circ} \mathrm{C}$ and $65 \% \mathrm{RH}$.

Table 6. The percentage change of resonant frequency of mix $\mathrm{CP}$ relative to mix $\mathrm{C}\left(\frac{F_{C P}-F_{C}}{F_{C}} \times 100 \%\right)$

\begin{tabular}{|c|c|c|c|}
\hline \multirow{2}{*}{ Ages (days) } & \multicolumn{3}{|c|}{ Curing conditions } \\
\cline { 2 - 4 } & $\begin{array}{c}\text { a } \\
\text { (air curing at } 25^{\prime \prime} \mathrm{C} \text { at all } \\
\text { ages) }\end{array}$ & $\begin{array}{c}27 \mathrm{w} \\
\text { (water curing at } 27^{\circ} \mathrm{C} \text { for } 7 \text { days } \\
\text { and air curing) }\end{array}$ & $\begin{array}{c}38 \mathrm{w} \\
\text { (water curing at } 38^{\circ} \mathrm{C} \text { for } 7 \text { days and } \\
\text { air curing) }\end{array}$ \\
\hline 3 & $-1,8 \%$ & $-0,4 \%$ & $-0,8 \%$ \\
\hline 7 & $-0,8 \%$ & $-0,8 \%$ & $-0,5 \%$ \\
\hline 28 & $-1,4 \%$ & $0,3 \%$ & $-0,3 \%$ \\
\hline 91 & $-1,7 \%$ & $0,4 \%$ & $-0,7 \%$ \\
\hline
\end{tabular}

where $F_{C}$ represents the resonant frequency of mix C

$F_{C P}$ represents the resonant frequency of mix $\mathrm{CP}$

Table 7. The percentage change of resonant frequency of mix CPF relative to mix $\mathrm{CP}\left(\begin{array}{c}F_{C P F}-F_{C P} \times 100 \% \\ F_{C P}\end{array}\right)$

\begin{tabular}{|c|c|c|c|}
\hline \multirow{2}{*}{ Ages (days) } & \multicolumn{3}{|c|}{ Curing conditions } \\
\cline { 2 - 4 } & $\begin{array}{c}\mathrm{a} \\
\text { (air curing at } 25^{\circ} \mathrm{C} \text { at all } \\
\text { ages) }\end{array}$ & $\begin{array}{c}27 \mathrm{w} \\
\text { (water curing at } 27^{\circ} \mathrm{C} \text { for } 7 \text { days } \\
\text { and air curing) }\end{array}$ & $\begin{array}{c}38 \mathrm{w} \\
\text { (water curing at } 38^{\circ} \mathrm{C} \text { for } 7 \text { days and } \\
\text { air curing) }\end{array}$ \\
\hline 3 & $-0,2 \%$ & $-0,8 \%$ & $-1,5 \%$ \\
\hline 7 & $-0,5 \%$ & $-1,0 \%$ & $-0,8 \%$ \\
\hline 28 & $-0,1 \%$ & $1,0 \%$ & $0,1 \%$ \\
\hline 91 & $0,0 \%$ & $0,7 \%$ & $0,5 \%$ \\
\hline
\end{tabular}

where $\quad F_{C P}$ represents the resonant frequency of mix $\mathrm{CP}$

$F_{C P F}$ represents the resonant frequency of mix CPF

Under air condition, mix CPF produces slightly lowered frequency (about $0,2 \%$ and $0,5 \%$ at 3 and 7 days respectively) than mix $\mathrm{CP}$ but there is no difference at 91 days. Under $27 w$ and $38 w$ conditions, mix CPF also gives slightly lowered values than mix $\mathrm{CP}$ at early ages but it is about $0,5 \%$ higher than mix $\mathrm{CP}$ at later ages (28 and 91 days).

In fact, the water condition enhances the pozzolanic effect of PFA in FRC so as to increase the value of resonant frequency. At early ages, PFA affects the reac- 
tion rate of calcium aluminates and calcium silicate. The resonant frequency increases in later ages due to the pozzolanic reaction of fly ash. The activity of fly ash contributes to reduce the porosity at later ages. In the long term, the alkali soluble silica and alumina from the glass phase of PFA react with lime to form the calcium aluminate and calcium silicate hydrates which assist to reduce the concrete porosity. The result is similar to the effect of PFA on ordinary cement concrete [11].

\subsection{Resonant frequency of PFRC under the influence of SF}

From Fig 1, with the partial replacement by SF on PFRC, the resonant frequency of mix CPS is always higher than that of mix CP (without silica fume) at all ages under each curing condition. Table 8 shows the percentage change of mix CPS comparing with mix CP.

As can be seen in Table 8 , the frequency increases from $1,4 \%$ to $3,8 \%$ under the presence of SF on PFRC. There are two reasons for this. Firstly, because of the small particle size, SF acts as filler to fill the spaces between cement grains [12]. This results in a reduction in the size of the individual pores and voids in the paste. Secondly, more calcium hydroxide is converted to calcium silicate hydrate due to the pozzolanic reaction. Hence, the calcium silicate hydrate is more gel-like and much denser than that of Portland cement, therefore the pores are greatly reduced and enhances the resonant frequency.

\subsection{Effect of curing conditions}

Fig 1 also shows that the all mixes are under different conditions. The frequency of each mix increases in the following order: $a<27 w<38 w$. From this figure, concrete specimens stored under water curing for 7 days gives higher resonant frequency than air curing. Table 9 shows the relative percentage of resonant frequency of each mix relating to those concrete mixes under $27 w$ condition at 28 days.

Under the air curing, excess water is evaporated from the concrete so more voids are formed in the paste. The relative percentages of air curing are smaller than that of the $27 w$ condition. As a result, the concrete mix stored under air curing gives a lower resonant frequency than under water curing.

From Fig 2, air curing shows negative effect on both OPF and PFRC mixes when compared with $27 \mathrm{w}$ condition. For instance, the reduction percentages at 28 days for air curing are $3 \%, 4 \%, 5 \%$ and $3 \%$ for mix $\mathrm{C}$, mix $\mathrm{CP}$, mix CPF and mix CPS respectively compared with $27 \mathrm{w}$ condition. Neville [13] stated that hydration at a maximum rate can proceed only under condition of saturation. Under the $27 \mathrm{w}$ and $38 \mathrm{w}$ conditions, more water filled-spaces are filled by hydration products at early age.

Although the water-cured specimens are kept in air curing after 7 days, the resonant frequency is still higher than that of air-cured specimens. Even if there is water loss after 7 days for the water-cured specimens, the matter content is still higher than that of the air cured specimens. Therefore air curing reduces the resonant frequency of the concrete mixes compared with $27 \mathrm{w}$ condition and it implies that water curing for 7 days is very important for the hydration either at early or later ages.

Besides, the warm water curing $\left(38^{\circ} \mathrm{C}\right)$ provides a good curing condition for the hydration. Table 9 shows that the relative percentage under $38 \mathrm{w}$ condition is always higher than the $27 w$ condition for different ages. This implies that $38^{\circ} \mathrm{C}$ warm water curing accelerates the hydration of cement to fill the void rapidly, so $38 \mathrm{w}$ curing condition encourages the gain in the frequency of each mix. Also, from Figure 2, the increased percentages of resonant frequency at 28 days for $38 \mathrm{w}$ conditions are $2 \%, 1 \%, 1 \%$ and $2 \%$ for mix $\mathrm{C}$, mix CP, mix CPF and mix CPS respectively compared with $27 \mathrm{w}$ condition. Therefore the warm water method (38w condition) reports a positive effect on $\mathrm{OPC}$, fibre concrete and fibre concrete with pozzolans, and this improves the development of resonant frequency.

\section{Conclusions}

According to the experimental results, it can be concluded that:

- The presence of polypropylene fibres gives little effect on the resonant frequency. The resonant frequency of the fibre concrete shows less than $1 \%$ increase when

Table 8. The percentage change of resonant frequency of mix CPS relative to mix $\mathrm{CP}\left(\frac{F_{C P S}-F_{C P}}{F_{C P}} \times 100 \%\right)$

\begin{tabular}{|c|c|c|c|}
\hline \multirow{2}{*}{$\begin{array}{c}\text { Ages } \\
\text { (days) }\end{array}$} & \multicolumn{3}{|c|}{ Curing conditions } \\
\cline { 2 - 4 } & $\begin{array}{c}\mathrm{a} \\
\text { (air curing at } 25^{\circ} \mathrm{C} \text { at } \\
\text { all ages) }\end{array}$ & $\begin{array}{c}27 \mathrm{w} \\
\text { (water curing at } 27^{\circ} \mathrm{C} \text { for } 7 \text { days } \\
\text { and air curing) }\end{array}$ & $\begin{array}{c}38 \mathrm{w} \\
\text { (water curing at } 38^{\circ} \mathrm{C} \text { for } 7 \text { days } \\
\text { and air curing) }\end{array}$ \\
\hline 3 & $3,0 \%$ & $1,8 \%$ & $1,5 \%$ \\
\hline 7 & $2,2 \%$ & $2,0 \%$ & $1,4 \%$ \\
\hline 28 & $2,3 \%$ & $1,4 \%$ & $1,6 \%$ \\
\hline 91 & $2,4 \%$ & $1,6 \%$ & $3,8 \%$ \\
\hline
\end{tabular}

where $F_{C P}$ represents the resonant frequency of mix CP

$F_{C P S}$ represents the resonant frequency of mix CPS 
Table 9. The relative percentage of resonant frequency of each mix under different curing conditions relating to those mixes under $27 \mathrm{w}$ condition at 28 days

\begin{tabular}{|c|c|c|c|c|c|}
\hline \multirow{2}{*}{ Mix } & \multirow{2}{*}{ Curing conditions * } & \multicolumn{4}{|c|}{ Relative percentage compared with the strength under $27 \mathrm{w}$ condition at 28 days } \\
\cline { 3 - 6 } & & 3 days & 7 days & 28 days & 91 days \\
\hline $\mathrm{C}$ & & $90,6 \%$ & $93,9 \%$ & $97,4 \%$ & $98,2 \%$ \\
\hline $\mathrm{CP}$ & $\mathrm{a}$ & $88,7 \%$ & $92,8 \%$ & $95,8 \%$ & $96,3 \%$ \\
\hline $\mathrm{CPF}$ & & $87,7 \%$ & $91,5 \%$ & $94,7 \%$ & $95,4 \%$ \\
\hline $\mathrm{CPS}$ & & $90,0 \%$ & $93,5 \%$ & $96,6 \%$ & $97,2 \%$ \\
\hline $\mathrm{C}$ & & $93,0 \%$ & $98,1 \%$ & $100 \%$ & $101,1 \%$ \\
\hline $\mathrm{CP}$ & $27 \mathrm{w}$ & $92,4 \%$ & $97,0 \%$ & $100 \%$ & $101,1 \%$ \\
\hline $\mathrm{CPF}$ & & $90,8 \%$ & $95,1 \%$ & $100 \%$ & $100,8 \%$ \\
\hline $\mathrm{CPS}$ & & $92,7 \%$ & $97,6 \%$ & $100 \%$ & $101,3 \%$ \\
\hline $\mathrm{C}$ & & $96,0 \%$ & $100,3 \%$ & $102,0 \%$ & $103,0 \%$ \\
\hline $\mathrm{CP}$ & $38 \mathrm{w}$ & $94,9 \%$ & $99,5 \%$ & $101,4 \%$ & $102,0 \%$ \\
\hline $\mathrm{CPF}$ & & $92,6 \%$ & $97,8 \%$ & $100,5 \%$ & $101,5 \%$ \\
\hline $\mathrm{CPS}$ & & $95,0 \%$ & $99,4 \%$ & $101,5 \%$ & $104,4 \%$ \\
\hline
\end{tabular}

Notes: ${ }^{*}$ a $=$ air curing at $25^{\circ} \mathrm{C}$ and $65 \%$ RH. at all ages

$27 \mathrm{w}=$ water curing at $27^{\circ} \mathrm{C}$ for 7 days and then air curing at $25^{\circ} \mathrm{C}$ and $65 \% \mathrm{RH}$.

$38 \mathrm{w}=$ water curing at $38^{\circ} \mathrm{C}$ for 7 days and then air curing at $25^{\circ} \mathrm{C}$ and $65 \% \mathrm{RH}$.

compared with that of the plain concrete.

- Under the influence of PFA, the resonant frequency is slightly decreased at early ages but then is increased at later ages compared with the ordinary fibre concrete.

- The advantage of using PFA in plain concrete would also apply to PFRC. The mechanical properties of fibre concrete are improved by the pozzolanic reaction of PFA.

- The resonant frequency of SF fibre concrete is higher when compared to that of ordinary fibre concrete.

- Polypropylene fibre reinforced concrete incorporating silica fume is benefited from the improvement provided by SF to plain concrete. The mechanical properties of fibre concrete are improved by the pozzolanic reaction of SF.

- Concrete specimens cured under $25^{\circ} \mathrm{C}$ air curing indicates decreased resonant frequency compared with $27 \mathrm{w}$ curing conditions. The drying effect in the air curing decreases the gain in the development of mechanical properties.

- The air curing method reduces the gain in the rate of pozzolanic reactions of PFA and SF compared with $27 \mathrm{w}$ condition therefore the mechanical properties are not improved significantly by the pozzolanic reaction under air curing.

- The initial water curing for 7 days is essential for improvement of the mechanical properties at all ages compared with air curing because the early water curing appears to provide a good condition for the hydration and the pozzolanic reaction.

- The specimens cured under $38 \mathrm{w}$ curing condition show higher mechanical properties than those specimens cured under $27 \mathrm{w}$ curing condition. The warm water temperature $\left(38^{\circ} \mathrm{C}\right)$ accelerates the gain in the mechanical properties. Also, the pozzolanic reactions of PFA and SF are also be enhanced. The mechanical properties of fibre concrete with pozzolans improve under $38 \mathrm{w}$ condition compared with $27 \mathrm{w}$ condition.

\section{References}

1. Bentur A. Fibre Reinforced Cementitious Composites. London: Elsevier Applied Science, 2000.

2. Ramakrishnan V. Materials of Fibre Reinforced Concrete In: Proc., Inter. Sym. on Fibre Reinforced Concrete. Madaras, India, Vol 1, December 16-19, 1987, p 2.3-2.23.

3. Houde J., Prezeau A. and Roux R. Creep of Concrete Containing Fibers and Silica Fume. Fiber Reinforced Concrete Properties and Applications, ACI, Detroit, Michigan. SP 105-6, 1987, p 101-120.

4. ACI Committee 544. Synthetic and Other Non-metallic Fibre Reinforcement of Concrete, ACI Compilation 28, ACI, Detroit, Michigan. 1994.

5. ACI Committee 544. State of the Art Report on Fiber Reinforced Concrete, ACI 544.1R-82, ACI, Detroit, Michigan. 1982.

6. Mehta P. K. Concrete: Structures, Properties and Materials. Prentice-Hall, Inc., 1986.

7. Grace W. R. Product Information of Grace Fibre. W.R. Grace (H.K.) Ltd., 1993.

8. Malhotra V. M. and Carino N. J. HandBook on Nondestructive Testing of Concrete. CRC Press, 1991.

9. Balendran R. V. Building Materials Laboratory Manual 2. Department of Building and Construction: City Polytechnic of Hong Kong, Hong Kong, 1993.

10. BS 1881: Part 209:1990. Recommendations for Measurement of Dynamic Modulus of Elasticity. 1990.

11. ACI Committee 226. Use of Fly Ash in Concrete. ACI Material Joumal. ACI, Detroit, Michigan, 1987, 84: p 381-409.

12. ACI Committee 226. Silica Fume in Concrete. ACI Material Journal. ACI, Detroit, Michigan, 1987, 84: p 158-166.

13. Neville A. M. Properties of Concrete. 3rd ed. Longman Scientific \& Technical, New York, 1986. 